\title{
"Well done old half breed woman": Lydia Campbell and the Labrador Literary Tradition
}

\author{
Kristina Fagan*
}

In 2009, Lydia Campbell (1818-1905), a Labrador writer of Inuit and English parentage, was designated by the Canadian government as "a

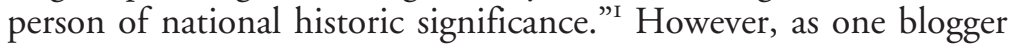
from Labrador commented, "We all knew she was significant' round these here parts for quite some time." For the Inuit and Inuit Metis of Labrador, ${ }^{3}$ Campbell's i894-5 autobiography, Sketches of Labrador

* Kristina Fagan is Labrador Metis and grew up in St John's, Newfoundland. She teaches Aboriginal literatures in the English Department at the University of Saskatchewan. She is a co-editor of Henry Pennier's autobiography, Call Me Hank: A Sto:lo Man's Reflections on Living, Logging and Growing Old, and Orality and Literacy: Reflections Across Disciplines, both from University of Toronto Press. She has a particular interest in oral storytelling practices and their relationship to identity, and her current research is on storytelling among the Labrador Metis.

I “Labrador Settler To Be Recognized," CBC News, 23 July 2009, http://www. cbc.ca/arts/books/story/2009/07/23/lab-settler-723.html, accessed 28 October 2009.

2 Aimee Chaulk, "Lydia Campbell Celebrated," Today at Them Days, posted 23 July 2009, http://themdays.wordpress.com/2009/07/23/lydia-campbellcelebrated/, accessed 28 October 2009.

3 Identity is a complex issue in Labrador. Historically, people of mixed Inuit and European descent in Labrador were referred to variously as Settlers, Planters, Liveyers, Halfbreeds (which is how Campbell proudly described herself), halfEskimo, Kablunangajuit, and Labradorians. In the present-day context, these terms are often confusing, misleading, or offensive. Furthermore, the Canadian government's system of designated Aboriginality has divided the mixed-blood Inuit into two groups, those who are designated as Inuit, and those who are not. The term "Metis" began to be used in Labrador in the I970s, an import from Western Canada, as a way to describe the aboriginality of those who did not meet the conditions to be officially Inuit. Thus, some of Lydia Campbell's descendents are identified as Inuit, members of Nunatsiavut, while others are members of the Labrador Metis Nation (now Nunatukavut). In this essay, I use the terms "Inuit" and "Inuit Metis" to describe these descendents, who do, despite issues of categorization, share the same ancestry and culture. It should be noted, however, that for the sake of simplicity, I sometimes use the term "Inuit Metis" to describe those of mixed Inuit and European descent, regardless of which Aboriginal organization they belong to. 
Life by a Labrador Woman, has had a long-time and profound impact in terms of local identity, sense of history, and practices of reading and writing. While this significance has been recognized within the context of Newfoundland and Labrador studies, Campbell's work is little known outside the province and has generally not been recognized within the field of Canadian Aboriginal literature. ${ }^{4}$ This is unfortunate, because Campbell's writing challenges many common critical assumptions about Aboriginal literature, particularly the oppositional framework that sees Aboriginal writing as primarily defined by a tension between the "white" and "Aboriginal" worlds, or between colonialism and resistance. Lisa Brooks has argued that, by focusing on this oppositional Native/white framework, critics have "failed to see a full picture": "Most critics have portrayed early Native writers either as individuals 'caught between two worlds' or as 'subjects,' who, even as they may have resisted or challenged the colonial world, struggled to exist within it. The degree to which they were corrupted by writing, by Christian religion, and by their presence in European circles is almost inevitably raised." This focus

4 Campbell's writings, for instance, have not appeared in any anthologies of Native Literature in Canada. She has, however, received substantial attention from literary scholars who are either from or are based in Newfoundland and Labrador, suggesting that her significance has been recognized in a local context. Dale Blake, "Women of Labrador: Realigning North from the site(s) of metissage," Essays on Canadian Writing 59 (Fall 1996): 164-82; Roberta Buchanan, "Autobiography as History: The Autobiographies of Three Labrador Women - Lydia Campbell, Margaret Baikie and Elizabeth Goudie," in Their Lives and Times: Women in Newfoundland and Labrador, A Collage, ed. Carmelita McGrath, Barbara Neis, and Marilyn Porter (St John's: Killick Press, 1995), 67-74; Roberta Buchanan, “'Country Ways and Fashions': Lydia Campbell's 'Sketches of Labrador Life,' A Study in Folklore and Literature," in Studies in Newfoundland Folklore: Community and Process, ed. Gerald Thomas and J.D.A. Widdowson (St John's: Breakwater Books, I99I), 289-308; Roberta Buchanan, "Autobiography as Popular Culture: Autobiographies of Labrador Women" (paper delivered at the Popular Culture Association, Atlanta, Georgia, I986), copy in the Centre for Newfoundland Studies, Memorial University of Newfoundland; Robin McGrath, Canadian Inuit Literature: The Development of a Tradition, Canadian Ethnography Service Paper 94 (Ottawa: National Museums of Canada, 1984), 84-85; Renée Hulan, Northern Experience and the Myths of Canadian Culture (Montreal: McGill-Queen's University Press, 2002), $82-87$.

5 Lisa Brooks, "Digging at the Roots: Locating an Ethical, Native Criticism," in Reasoning Together: The Native Critics' Collective, ed. Craig Womack, Daniel Heath Justice, and Christopher Teuton (Norman: University of Oklahoma Press, 2008), 234-64. 
on colonial influence, Brooks continues, obscures the ways in which Aboriginal writing "is part of an extensive indigenous intellectual tradition." The purpose of this essay is to place Campbell within such an indigenous tradition, the Labrador literary tradition, exploring the historical and culturally specific context within which Campbell wrote and the influence that her book has had among the Labrador Inuit Metis. Thus, I am primarily interested, not in a close reading of Sketches, but in the ways that Campbell's writing was created and has been received in a social context.

Because of the popular post-colonial approach to Aboriginal literature, critics have paid little attention to this social context, to the ways in which literature emerges out of and functions within Aboriginal communities, which Creek literary critic Craig Womack has called "Native literature's place in Indian country." As a result, those critics who have written on Campbell have often emphasized, not her relationship to her own community, but the ways in which she was "acculturated" to European ways. Renée Hulan, for example, argues that, in works such as Campbell's, "writing one's life story began as a religious imperative, encouraged by Christian missionaries, and, as such, early examples tend to show the author's appreciation for and assimilation into the new, colonizing culture." Hulan goes on to claim that Campbell distances herself from the Inuit and that, with its "Christian themes," her writing "show[s] signs of colonial acculturation through identification with the authority figure endorsing the work and disavowal of the aboriginal mother." 8 However, to describe Campbell's work as primarily motivated by a desire to "please her Anglican clergyman" is to misrepresent the cultural and historic context in which she wrote. For Lydia Campbell, to write her story was to engage in an activity that was widely valued by the Labrador Inuit and Inuit Metis. Moreover, I will argue that

6 Brooks, "Digging at the Roots," 235.

7 Craig Womack, Red on Red: Native American Literary Separatism (Minneapolis: University of Minnesota Press, I999), II. In the United States, critics such as Craig Womack and Daniel Heath Justice have begun the work of examining Aboriginal literature in a community-specific context.

8 Hulan, Northern Experience, 82-83. Roberta Buchanan, similarly, comments that Campbell "participated in both cultures [Inuit and English], although the white paternal culture dominated" (“Country Ways and Fashions,"” 294). And Dale Blake argues that Campbell's writings "document the loss of Native agency occasioned by the arrival of the white man" ("Women of Labrador," I65).

9 Hulan, Northern Experience, 83. 
her Sketches were not an expression of assimilation, but of a blending of cultures that has been part of daily life and identity for the Inuit Metis.

The circumstances of Lydia Campbell's life may appear, at first glance, to make her an unlikely writer. The daughter of an English father, Ambrose Brooks, and an Inuit mother, who is remembered as Susan, Campbell was born in I818 in Hamilton Inlet in Central Labrador. Ambrose Brooks had fled the press gangs of England during the Napoleonic wars, and, as his daughter would later explain, "he and a lot more English people came out up the shore for wood cutters and sealing fishing and cod fisherys was the highest in those days." ${ }^{\text {"I }}$ He married an Inuit orphan from the Rigolet area, at the mouth of Hamilton Inlet, and they settled at Mulligan, on the northern shore of the Inlet, and raised three daughters, of whom Lydia was the youngest. ${ }^{\text {II }}$ In the nineteenth century, Hamilton Inlet (also called "Esquimaux Bay") was profoundly isolated from Newfoundland and Canada, receiving outside visits only from fur traders and the occasional missionary. Campbell lived her entire life in the inlet, hunting, fishing, gathering, and trapping. She was married twice, first to William Blake (1793-1845), also a "halfbreed" from Hamilton Inlet, and then, after Blake's death, to Daniel Campbell (I822-I900) from the Orkney Islands, and she gave birth to eleven children and adopted one, only six of whom made it to adulthood. ${ }^{\mathrm{I2}}$ She had no

Io Lydia Campbell, Sketches of Labrador Life by a Labrador Woman, in The Evening Herald (St John's), 6 December 1894, p. 3. It is not known whether Ambrose Brooks was affiliated with any merchant company. Lynne Fitzhugh suggests that his name could probably be "found in ship's manifests for Bird \& Company or Slade's," merchants from England and Newfoundland respectively. Lynne Fitzhugh, The Labradorians: Voices from the Land of Cain (St John's: Breakwater Books, I999), 315-16.

II While, like most marriages in Labrador at the time, it is unlikely that Ambrose and Susan Brooks were married by a minister, their marriage was long-lasting. They were together until Susan's death in I829, and Lydia Campbell writes about her childhood home: "we lived up in the river head in a long Bay and no one near us, nearer than about 70 miles from any body. I think we lived happy together, until our dear sister Elizabeth got married to a young half-breed as we was that was my first grief to leave her behind" (Campbell, 6 December I894).

I2 I have attached, in an appendix, a family tree that includes Lydia Campbell's parents, Campbell and her two sisters, and their husbands and children. A more extensive family tree would be excessively long and unwieldy. However, later in this essay, when I refer to Campbell's descendents, I will indicate, in a note, to which family line they belong. The information in this family tree is largely 
formal schooling and very limited access to books or writing materials. Yet, at age 75 , while more than ever providing for her family since her husband's health was failing, and with three of her grandchildren in her care, she sat down and wrote a book. In fact, it was not her first time doing so; she comments, "I had my life wrote down and gave it to the Rev. A.A. Hadams, but he lost it." ${ }^{\text {'13 }}$ Her writings include not only her life story, but also the stories of her parents and other community members, as well as traditional Inuit and Innu narratives. Her writings were published in serial form between I894 and I895 in the Evening Herald, a St John's newspaper, under the title Sketches of Labrador Life by a Labrador Woman. ${ }^{14}$

What led Lydia Campbell to write? To answer this question we must understand the role of reading and writing in nineteenth-century Labrador, a role that challenges some common assumptions about Aboriginal people's relationship to literacy. Literacy is widely seen within Aboriginal studies as a tool and effect of colonialism; Kimberly Blaeser, for instance, points out that, in Aboriginal literature, literacy is often depicted as the enemy:

Whether pictured as helpless victims of a system of literacy designed to eliminate or immobilize them, pictured struggling to resist the assimilation implied in literacy and to preserve tribal cultures, pictured working for the competence in English necessary in the battle for political power, or pictured as masters of the English

from Leslie Baikie, Up and Down the Bay: The Baikie Family of Esquimaux Bay (unpublished, available in the Centre for Newfoundland Studies, Memorial University, 1989).

I3 Campbell, Sketches of Labrador Life, 6 December 1894. Campbell gave her first autobiography to Reverend A.A. Holmes. He probably lost it during an incident in December I888. Holmes' boat was driven out to sea for six days and he was stranded on George Island, losing his boat and all of his travelling gear. This incident is described in Arminius Young, A Methodist Missionary in Labrador (Toronto: S. and A. Young, I916), 26-29.

I4 Since there is no published edition of Lydia Campbell's work that includes all her writing as it appeared in The Evening Herald from I894 to I895, I have used my own unpublished transcription from the newspaper. Thus, quotations from Sketches of Labrador Life are hereafter cited in the text using the dates on which they appeared in The Evening Herald: Campbell, Sketches of Labrador Life, in The Evening Herald (3, 4, 6, 7, 10, I2, I3, 17, 18, 20, and 24 December 1894): 3; (6 February 1895): 4; (I7 May 1985): 3. Readers looking for a more accessible version of Campbell's work can consider the following editions, but should be aware that they are incomplete: Lydia Campbell, Sketches of Labrador Life, ed. Doris Saunders (Happy Valley, NL: Them Days, 1980); Lydia Campbell, Sketches of Labrador Life (St John's: Killick Press, 2000). 
language who have turned the weapons of literacy back on the colonial system, many of the protagonists of Native American literature are engaged in confrontations with literacy and its attendant circumstances. ${ }^{\text {I5 }}$

However, such confrontations are not the only relationship that Aboriginal people have had with literacy. In Central Labrador, the Inuit and Inuit Metis people made writing their own and literacy was widespread and valued there in the nineteenth century. Despite the fact that there were no schools in Central Labrador during Lydia Campbell's lifetime, as Arthur Waghorne notes in his introduction to Campbell's work, of the 2,719 people living between Groswater Bay (Central Labrador) and Blanc Sablon (Southern Labrador) in I891, I,I50 could read and 906 could write. ${ }^{16}$ This relatively high rate of literacy was due to a number of factors. ${ }^{17}$ One was the indirect influence of the Moravian missionaries who worked among the Inuit in Northern Labrador and began teaching them to read and write in the I78os. The Moravian approach to Aboriginal education differed significantly from that seen in much of Canada. The Moravians set up day schools to teach the Inuit people to read and write in their own language of Inuktitut and set up a printing press in Nain for the production of Inuktitut reading materials. They taught the children only during the winter, when the Inuit had returned from seasonal hunting and fishing, so as not to interfere with traditional activities, taught both boys and girls, and trained Inuit teachers. ${ }^{18}$ They also appear to have been gentle teachers; one missionary noted in 1782 , "One cannot say one hard word to a flighty boy or girl, or even use a loud voice. That is against their way of raising [children]. If one forgets, they will be kunovok, i.e. unhappy, and stay [away] from

I5 Kimberly M. Blaeser, "Learning 'The Language the Presidents Speak': Images and Issues of Literacy in American Indian Literature," World Literature Today 66 (1992): 230.

I6 Arthur Waghorne, Introduction to Sketches of Labrador Life by Lydia Campbell, 3 December 1894.

I7 For a more detailed discussion of literacy among the Labrador Inuit and Inuit Metis, see Robin McGrath, "The History of Inuit Literacy in Labrador," Newfoundland Quarterly 87, no.I (Fall I99I/Winter 1992): 35-40.

I8 For an explanation of the Moravian approach to education in Labrador, see Hans Rollmann, "Moravian Education in Labrador: A Legacy of Literacy," in Symposium 2008: Post-Confederation Education Reform - From Rhetoric to Reality, ed. Gerald Galway and David Dibbon (St John's: Faculty of Education, Memorial University, 2008), 227-36. 
school two or three times."19 The Moravians' approach to education appears to have been successful, as the Inuit took enthusiastically to literacy, using it for their own purposes and teaching one another outside of the missions. By I8Io, nearly all the Moravian Mission Inuit were literate in Inuktitut. ${ }^{20}$ And by the 1820 s, the missionaries sometimes conveyed as many as 50 letters at a time from Inuit in one community to relatives and friends in another. ${ }^{2 \mathrm{II}}$ The Moravians also provided some of the Inuit with exercise books in which to record their spiritual meditations and encouraged them to keep diaries in order to keep track of the Sabbath when away from the missionestablished towns. ${ }^{22}$ Other Inuit kept diaries in the white space in their Daily Texts, little books of Bible verses. ${ }^{23}$ In a famous example of Inuit diary-keeping, Abraham Ulrikab, a Labrador Inuit man who in I80o was transported with his family to Germany to be displayed in a zoo, kept a diary in Inuktitut about his ill-fated journey. ${ }^{24}$

But Lydia Campbell lived south of the Moravian-influenced communities. Can we assume that the development of literacy among the Northern Inuit would have influenced the Inuit and Inuit Metis of Central Labrador? In fact, despite Moravian efforts to prevent "their Inuit" from interactions with what they called the "heathern [sic]" Inuit who "lived to the southward,"25 the Inuit people moved back and forth along the coast of Labrador and there were extensive relations between the Moravian and non-Moravian Inuit. ${ }^{26}$ Hans Rollmann documents "significant evidence that literate Inuit from north coast communities taught fellow Inuit to read in Central Labrador." ${ }^{27}$ These efforts took place even when reading and writing materials were rare. A journalist visiting Labrador in I86I described how Joe Palliser of Hamilton Inlet had learned to write when living in the Moravian-run community of Okak and later maintained his

I9 Rollmann, "Moravian Education in Labrador," 229.

20 Fitzhugh, Labradorians, 199.

2I Rollmann, "Moravian Education in Labrador," 230.

22 McGrath, "History of Inuit Literacy," 37.

23 Rollmann, "Moravian Education in Labrador," 233.

24 Abraham Ulrikab, The Diary of Abraham Ulrikab, ed. and trans. Hartmut Lutz (Ottawa: University of Ottawa Press, 2005).

25 Brother Glitsch (Hopedale record of I838), quoted in Hugh Brody, "Permanence and Change Among Inuit and Settlers of Labrador," in Our Footsteps Are Everywhere: Inuit Land Use and Occupancy in Labrador ([Nain, NL]: Labrador Inuit Association, 1977), 314.

26 Fitzhugh, Labradorians, 200.

27 Rollmann, "Moravian Education in Labrador," 23I. 
ability by writing "upon a soft stone with a bit of iron." ${ }^{28}$ It seems clear that the Moravian influence would have been felt in Lydia Campbell's community. Moreover, due to the Moravian approach, it seems that literacy was seen, not as an imposition, but as a tool to be embraced by the Labrador Inuit.

But the Moravian influence is not the full story of literacy in Central Labrador. Literacy also arrived with the European men, many of them literate employees of the Hudson's Bay Company, who settled in Labrador and married Inuit women. Methodist missionary Arminius Young in 1916 wrote of these men: "Nearly a hundred and fifty years ago Englishmen began to settle in Labrador ... they brought with them their Bibles and taught their Eskimo wives to read the word of God." ${ }^{29}$ Reading and writing were then passed on from generation to generation in Inuit Metis families. Thus, when Hudson Bay factor John McLean visited Central Labrador in the I830s, he was "surprised to find them ["half-breeds"] all able to read and write, although without schools or school-masters. The task of teaching devolves upon the mother; should she (what seldom happens) be unqualified, a neighbour is always ready to impart the desired instruction. ${ }^{30}$ Richard Knight, a Wesleyan missionary, found the same practice as far south as Square Islands in 1925: "The master of the family had lived with an Indian female, by which he had five children. I never saw more fine and healthy children and I am happy in being able to add that he has paid more attention to these than we generally find under such circumstances. He had taught his two oldest daughters to read." ${ }^{1}$ Such instruction within the family appears to have been how Lydia Campbell learned to read. Young, who met her in 1903, reported:

I learned from Mrs. Campbell that her father was a good singer and was interested in the education of his children. He spared them no pain in teaching them how to sing and read. This might have been the extent of their education for [Ambrose] Brooks thought his halfbreed children could get along very well on the Labrador

28 Charles Hallock, “Three Months in Labrador," Harper's New Monthly Magazine 22 (I86I): 749-50.

29 Young, Methodist Missionary in Labrador, Io.

30 John McLean, Notes of a Twenty-Five Years'Service in the Hudson's Bay Territory (London: Richard Bentley, I849), I6I-62.

3I Journal of Richard Knight, Methodist Missionary in Labrador (I825), vol. I2; typescript available in Labrador Metis Nation Archives, Happy Valley-Goose Bay. 
without the knowledge of writing. The children, however, were ambitious and by perusing their father's letters and with what little help they received from him, they learned to write. In this way, practically all the children of middle Labrador learned to read and write. ${ }^{32}$

Literacy then was widespread and valued in the Inuit Metis community of Labrador. As Robin McGrath notes, in Labrador, "literacy was not seen as the prerogative of specialists but was seen as being a tool to everyday comfort and survival, much like the ability to use a gun or set a trap, a skill to be acquired from a parent, elder sibling or neighbour." 33 It was a skill that was willingly embraced and was part of people's daily lives. For instance, Margaret Baikie, Lydia Campbell's daughter, reports in passing in her own autobiography that her mother was reading a book lent to her by Donald A. Smith, a Hudson's Bay chief factor. ${ }^{34}$

Yet literacy alone is not enough to explain Lydia Campbell's writing of her life story. Many people are literate yet never engage in such an ambitious act. To imagine Campbell's motivation, it is important to understand her position within Central Labrador society. Within this society, Inuit and Inuit Metis people were not subjected to the pervasive and degrading racism and sexism seen in much of Canada at that time. This is because of Central Labrador's unique history, in which the Europeans and Newfoundlanders who settled there did not generally do so as part of a colonizing mission. They were neither sponsored nor governed in any meaningful way by an outside government nor were they part of a religious mission. Some were employees of the Hudson's Bay Company (HBC) while others were independent fishermen and fur traders. They married Inuit women and their Metis descendants were mostly independent trappers. These descendents generally spoke English (combined with Inuktitut words)

32 Young, Methodist Missionary in Labrador, I4. This practice continued in Labrador for many years. My grandmother, growing up in southern Labrador in the I920s and I930s, was taught to read within the family home but was not taught to write.

33 McGrath, "Inuit Literacy," 39.

34 Margaret Baikie, Labrador Memories (Happy Valley, NL: Them Days, I983), 9. In the I840s, Lydia Campbell worked as a cook for Donald Smith, who later became Lord Strathcona and who played an important role in the creation of the trans-Canadian railway. He is reported to have helped families in Labrador obtain books (Fitzhugh, Labradorians, 32I). He was also, later in life, a major benefactor to women's education, so it is possible that he encouraged Campbell's reading and writing. 
and practised Christianity, but dressed, ate, moved with the seasons, and lived off the land in Inuit ways. Anthropologist Hugh Brody suggests that Labrador's history is unique within North America: "Labrador is remarkable in the way that settler families have lived alongside Inuit for some I50 years. They constitute the only group of Europeans to make lives for themselves in North America more on the terms of an indigenous population than as representatives of a colonial enterprise." ${ }^{35}$ This lack of "colonial enterprise" also meant that Central Labrador did not have colonial institutions; Lynne Fitzhugh explains, "While northern and southern-most Labrador each enjoyed the advantages of organized community life and rudimentary social institutions early in the nineteenth century, the residents of central Labrador, Hamilton Inlet in particular, had no stationary institutions or permanent services, other than those provided by HBC." 36 This relative lack of outside-run institutions, however, may have in fact been an "advantage." While the Inuit Metis observed Christian practices, they did so within their family home, with little or no contact with ministers or missionaries. While they learned to read and write, they did not do so within schools. And while the $\mathrm{HBC}$ was an outside institution, it valued the Inuit Metis as trading partners. As such, the Inuit Metis of Labrador did not face many of the racist messages that were impressed upon Aboriginal people in the government and church-run institutions active in Aboriginal communities in much of Canada. ${ }^{37}$

Also, in a time when authorship was a role dominated by men, Lydia Campbell was part of a culture that generally valued women and their contributions. When European men married Labrador Inuit and Inuit Metis women in the eighteenth and nineteenth centuries, they depended on those women's knowledge of the land and how to live off of it. Moreover, when the men were away on the traplines, sometimes for months at a time, women did all the work to care for the family, including hunting and fishing. Lydia Campbell's daughter recalls that her father (Daniel Campbell) was not a very good trapper and

35 Hugh Brody, The Other Side of Eden: Hunters, Farmers, and the Shaping of the World (Vancouver: Douglas and McIntyre, 2000), 316. Note that the term "settlers" is often used in Labrador to refer to people of mixed Inuit and European descent.

36 Fitzhugh, Labradorians, 321.

37 This is not to suggest that racism did not exist in Labrador but that it was perhaps less prevalent than in some parts of Canada. 
that Lydia had to help him set the traps. ${ }^{38}$ The lack of clear division between men's and women's work appears to have led to women's labour being valued. Even at 75, when writing her autobiography, Campbell was still engaged in a wide range of work, including caring for her ailing husband and three grandchildren, and we can hear her pride as she lists the products of her labour:

I have been hunting most every day since Easter and to some of my rabbit snares and still traps, cat traps and mink traps. I caught 7 rabbits and one martin and I got a fox and 4 partridges about 500 trout - besides household duties - never leave out Morning and Evening prayers and cooking and baking and washing for 5 people -3 motherless little children - with all so much to make for sale out of seal skin and deer skin shoes, bags, and pouches and what not ... You can say, well done old half breed woman in Hamilton's Inlet. (13 December 1894)

While Campbell may sound exceptional, this range of work was common for women in her community. Doris Saunders, one of Campbell's descendants, ${ }^{39}$ when asked by the Canadian Women's Studies Journal to write about women's role in Labrador, reflected, "I'm having great difficulty here because as I write this I see that there is no real difference between what the males and females did. Women generally looked after the house and children, but the men did too whenever it was necessary. Men did the outdoor jobs and provided for the family, but so did the women when they had to."40

In a talk she gave on the subject, Saunders further mused, "From all I have read and heard about my grandparents and so on down through the generations, except for Bill Blake, the women were treated equal."4I Bill Blake was Lydia Campbell's first husband, who forced her to marry him against her will when she was sixteen, a chapter in her life story Campbell told to Arminius Young in 1905 and which he reported in detail in his memoirs. ${ }^{42}$ The fact that Campbell spoke

38 Baikie, Labrador Memories, 2.

39 Doris Saunders was a descendant of Thomas Blake, Lydia Campbell's eldest son, and his first wife, Hester Ann Sheppard.

40 Doris Saunders, “A Daughter of Labrador," Canadian Women's Studies II (I980): I05.

4I Doris Saunders, "Women in Labrador" (unpublished speech given to Canadian Research Institute for the Advancement of Women, Halifax, date unknown), p. 6, Them Days Archives, Happy Valley-Goose Bay, Labrador.

42 Young, Methodist Missionary in Labrador, I6-I8. Young recounts that Blake invited Lydia and her father to a social gathering in Rigolet, where he proceeded 
openly of her mistreatment by Blake suggests that she felt she had the right to protest, and the fact that Blake's trickery is still remembered in Labrador as exceptionally bad behaviour is further evidence that such treatment of a woman has been seen there as unacceptable. We can hear a similar disapproval of the mistreatment of women in the words of Flora Baikie, ${ }^{43}$ who was one of the "motherless children" that Lydia mentions above; Baikie recalled in 1975 what Lydia Campbell had said about how Ambrose Brooks beat his Inuit wife, Susan:

And she [Lydia] said they killed some deer once and her father and them all went off and she and her mother got this deer all skinned and cut up and everything. And every now and then, she said, her mother was eatin' a piece of raw meat with fat on it. And so when he [her father] came home she told 'en that her mother was eatin' raw meat. And he got a piece of rope and give her a hammerin'. I was sayin' twouldn't be only me that got the cracks if 'twas me he hammered. Raw deer's meat is good, a piece of the raw fat is real good, you know, not the deer meat, the raw fat. I've a said 'twouldn't been only me got the hammerin'. ${ }^{44}$

Baikie's story reveals that women were sometimes beaten, and also shows that some traditional Inuit practices, such as eating raw fat, were disapproved of by the European newcomers. However, Baikie's response to the incident, which perhaps echoes her grandmother's, is to say that she would have fought back against such abuse and to defend the eating of raw fat, which she says she herself enjoys.

Lydia Campbell lived within a culture in which she was not profoundly devalued as an Aboriginal person or as a woman. She had a sense of her own abilities and accomplishments and a belief that she had the right to good treatment. Surely this strong sense of

to get her father drunk, and, with the help of others, forced Lydia to marry him: "Lydia insisted that she would not have Bill. Her feelings were not regarded, and two cruel women began at once to remove her old dress. The girl resisted but it was all of no avail; she was powerless in their hands and forced to submit to the inevitable. Blake came in and she was compelled to stand beside him, while some servant at the station read the marriage ceremony" (I8).

43 Flora Baikie was the daughter of Thomas Blake, Lydia's eldest son, and his second wife, Sarah Jane Oliver, who died in 1892, leaving her children to be raised by Lydia Campbell. Baikie, having been raised by her grandmother, knew many old stories, and, late in her life, became an important contributor to Them Days.

44 Flora Baikie, interview by Doris Saunders and Nigel Markham, 28 March 1975, transcript Foo4, Them Days Archives. 
self was key to her decision to write her life story and Campbell's confident personality is evident throughout her writing. She clearly felt that what she had to say was important, even to readers outside of Labrador. This attitude is also evident in the following description of her by Arminius Young. Young was an inexperienced missionary, newly arrived in Labrador, and the local people had gathered around the house where he was staying, curious about the new arrival, while he stayed shyly inside:

I saw, through the dining-room window that as she [Campbell] came along she had a word to say to everybody, and everybody had a word to say to her ... [After entering the house,] she clasped me by the hand and gave me a hearty welcome to Labrador. In about ten minutes she poured into my ears more information about Labrador and its people than I had received up to that time.

'I must go now,' she said, thinking she had given me all the information I needed, and putting her hands upon my shoulders, said:

'Now, my son, you must go out into the kitchen and talk to the people as the other ministers used to do.'

'Is that so?' I replied.

'Yes,' she said, 'if you don't the people won't like you.' I followed her into the kitchen. ${ }^{45}$

Young's anecdote reveals Campbell as a woman respected and liked within the community, with a sense of her authority as local historian and community representative, and uncowed by the authority of the missionary.

We can also see in Young's description that Campbell was confident in her knowledge of the history and traditions of her people. Much of the Labrador history that Young recounts in A Methodist Missionary in Labrador actually appears to have come from Lydia Campbell, as he repeats many stories found in her Sketches. Campbell "poured into [Young's] ears" many stories about Labrador, suggesting that she was an oral storyteller in addition to being a writer. She spoke Inuktitut, as well as English, so she had access to stories in both languages. ${ }^{46}$ In her writing, she draws heavily on both Inuit and Innu traditional stories as well as Inuit and Inuit Metis oral histories. Inuit Metis people have a strong tradition of storytelling, and there are clear

45 Young, Methodist Missionary in Labrador, 39.

46 Baikie, Labrador Memories, 7. 
continuities between Inuit and Inuit Metis storytelling traditions. ${ }^{47}$ The fact that Lydia Campbell had access to a large body of oral history and traditions and was practised in sharing them surely gave her a sense of content and form when she began to write. While Hulan argues that Campbell's writing shows "disavowal of the Aboriginal mother," ${ }^{8}$ Campbell in fact spends far more time explaining her Inuit mother's life history than her English father's. Her mother was an orphan who was mistreated by her Inuit people and fled alone along the shores of Hamilton Inlet:

she went along shore, crossing rivers on drift sticks and wading in shalow water, crossing points, throu woods, meeting bears, no gun, no axe, no fire works, but lye down under juniper tree and spruce tree. Who does it represent in the Bible. She had to travel all the way -70 miles - on foot. (7 December 1894)

Campbell's admiration for her mother is clear, which she emphasizes through her comparison of her mother to a biblical figure. This biblical reference need not be seen as oppositional to Campbell's Aboriginal identity. Womack has pointedly asked, "Are Indians always victims of Christianity?", going on to suggest that we consider the ways in which Aboriginal people make choices about religion. ${ }^{49}$ And indeed, while there is no doubt that Campbell was deeply Christian, her belief system was not passive. She comments, for instance, that she remembers when she was young "having no better thought that when a little child died, that his or her soul would be lost, as many are thinking yet, unless they are christened" but goes on to say that she now sees such a belief as "silliness," distinguishing her beliefs from those of "many" (24 December 1894). And Campbell often integrates Christian and Inuit beliefs; after having recounted the Inuit myth of the creation of the world through flood, she comments, "they can read it for themselves in the Bible what few there are in this bay" (20 December 1894), connecting the Inuit and Christian flood myths. ${ }^{50}$ Indeed, the Bible would probably have constituted Campbell's main

47 Mark Ferguson, "The Book of Black Hearts: Readdressing the Meaning and Relevance of Supernatural Materials," Journal of Canadian Studies 29 (Spring I994): IIO.

48 Hulan, Northern Experience, 83.

49 Craig Womack, "A Single Decade: Book-length Native Literary Criticism between 1986 and 1997," in Reasoning Together: The Native Critics Collective, 89.

50 Another example of the way in which Campbell integrates Christianity with her Aboriginality can be seen in her description of a death-bed dream by a settler 
written influence, and it blended with her extensive knowledge of oral traditions. ${ }^{5 \mathrm{I}}$

Lydia Campbell lived with a storytelling tradition that provided her with many stories to tell and the skills with which to tell them. She was literate and placed a high value on reading and writing. She had a sense of self-confidence. The final ingredient was the opportunity to write and publish, presented to her by Reverend Arthur C. Waghorne. ${ }^{52}$ Waghorne was born in London in I85I and was a Church of England missionary and an amateur botanist and folklorist. In 1892, Waghorne reports, he sent Lydia Campbell an "exercise book" and "begged her to be kind enough to write to me some account of Labrador life and ways" (3 December 1894). In giving Campbell the rare gift of paper, Waghorne gave Campbell an exceptional opportunity, as we can see in the final words she wrote: "I will try to make something better than all this if I live in the winter so please send me more envelopes if you please, and a little paper, so Good bye, - God bless you. Your faithful friend, LYDIA CAMPBELL" (17 May 1895).

It seems that Waghorne may have, in particular, asked Campbell to write about superstitions and myths (due to his interest in folklore), since Campbell titles several sections of her writing, "Superstition Still," "The Montaineer's Superstition," and "About Ghosts and other Things," etc. However, while Campbell tried to accommodate Waghorne's interests, it is also clear that she took control of this opportunity, using it to present an account of herself, her life, and her interpretation of the forces that had changed and shaped Labrador.

Waghorne also offered Campbell the opportunity for publication, a rare opportunity in a time when very few Aboriginal people saw their writing published..$^{53}$ We do not have any record of whether Waghorne discussed publication with Campbell, but there is evidence

named Lowe. The dream included Jesus and his mother, as well as "Indians" walking on water (20 December 1894).

5I The story of Lydia Campbell's mother, Susan, is still widely told in Labrador and the oral versions include many details that are not in Campbell's account, suggesting that the oral tradition has continued to live and develop alongside the production of writing.

52 This was actually her second effort at writing her life story (see note 13 ), which is further evidence of her strong motivation to write.

53 For instance, neither Edward Ahenkew (Cree), writing in Saskatchewan in the I920s, Mike Mountain Horse (Blood) writing at the same time in Alberta, nor Joseph Francis Dion (Cree), writing in Alberta between 1922 and 1960, were able to achieve publication of their writing during their lifetimes. All three were published posthumously. 
in her writing that she was aware that her words might be published; she refers to her audience as "my dear readers" and "whoever you are" (7 December 1894). ${ }^{54}$ Waghorne wrote up a "fair copy" of Campbell's work and sent it to the Evening Herald for publication. Again, luck came Lydia Campbell's way, for Waghorne was exceptional for his time in the respect that he showed for an Aboriginal person's words; he writes of his "especial regard for the Labrador people," and his hope that Campbell's writing might give others the "pleasure and interest" that it had given him. Furthermore, it appears that he did not attempt to significantly "correct" Campbell's non-standard English or unorthodox mixture of genres: "I have given my Labrador friend's account as she wrote it herself, except that I have here and there omitted a sentence or two of no particular interest, for the sake of brevity, and ventured to give a little punctuation, for the sake of rendering her narrative clearer" (3 December I894).

While we unfortunately cannot know what Waghorne chose to change, it appears that he did not significantly tamper with the text, since Campbell's writing appeared in the Evening Herald with spelling and grammar "mistakes," unusual and obscure words, no paragraph breaks, and so on. Waghorne's only major editorial input was an introduction and the occasional footnote. In 1987, Robin McGrath wrote of Inuit literature, "Editors and writers given the opportunity to work with native material must educate themselves so as to produce books as honest to the original material as they can possibly make them." 55 But Arthur Waghorne, nearly a century before, appears to have edited Campbell's work with this kind of honesty, which is especially fortunate since her original manuscript is lost.

Having considered the social factors which led Campbell to write, I would now like to consider the influence that her writing has had in her community. The influence that Aboriginal writers have had on one another has received little critical attention. In contrast, there have been many studies looking at the ways in which

54 The concept of publication was probably not foreign to Lydia Campbell. Her daughter, Margaret Baikie, recalls her mother reading a book (see note 34). Moreover, the Moravians in Northern Labrador had an active printing press and were printing a newspaper in Inuktitut, Aglait Illunainortut, in the nineteenth century. The Moravians also published letters and diary extracts by Inuit writers in their Periodical Accounts.

55 Robin McGrath, "Editing Inuit Literature: Leaving the Teeth in Gently Smiling Jaws" in Cross-Culturalism in Children's Literature, Proceedings of Children's Literature Association, 1987 (New York: Pace University, 1987), 4. 
Indigenous writers from around the world rewrite or respond to canonical works. However, as Lisa Brooks argues, if we "shift our gaze" away from colonial influence, "and instead look closely at the relationships and communications between these [Aboriginal] writers, a network of indigenous intellectual exchange comes to the fore." 56 To see such a "network of writing Indians," we must look beyond nationally recognized and available publications. ${ }^{57}$ Penny Petrone has described the period between the appearance of the poetry and prose of E. Pauline Johnson (186I-I9I3) and the flourishing of Aboriginal writing in the 1960 as a "barren period," 58 and Thomas King refers to a "gap of fifty-odd years where we do not see Natives writing." ${ }_{9}$ However, while Aboriginal people may not have been publishing in mainstream forums, this does not mean that there was not significant literary activity, both reading and writing, occurring within Aboriginal communities. Campbell's writings, for instance, after their 1895 publication in St John's, would not see publication again for nearly a century, until Them Days magazine began to publish excerpts in the late I970s. Despite this, however, Campbell's writing exerted significant influence in her own Inuit Metis community over the twentieth century, and many of Campbell's descendants also became writers.

First of all, we know that Lydia Campbell taught her children and grandchildren to write. Flora Baikie, her granddaughter, recalls, "I never went to school. Gran learned us our letters. She give us one of her letters she had from someone and we learned to write a little going by that. We all went through Tom's Dog. Gran learned us that. We could learn on our own by then. Tom's Dog was a spelling book. 'Twas only easy. I suppose people got easy books now for their little children. I haven't got no school learning but I can read a story when I got good light."

56 Brooks, "Digging at the Roots," 244.

57 Brooks, "Digging at the Roots," 254.

58 Penny Petrone, Native Literature in Canada: From the Oral Tradition to the Present (Toronto: Oxford University Press, 1990), 95.

59 Thomas King, "Native Literature in Canada," in Dictionary of Native American Literature, ed. Andrew Wiget (New York: Garland, 1994), 357-58.

60 Flora Baikie, "I Was Born in Mulligan," in The Labradorians: Voices from the Land of Cain, ed. Lynne Fitzhugh (St John's: Breakwater Books, 1999), 367. 
Jean Crane ${ }^{6 \mathrm{I}}$ Lydia's great-granddaughter, also recalls that Lydia Campbell taught her father her own distinctive self-taught form of writing: "She [Lydia] learned to read from the Bible and when she was asked to write about her life, she only had the scribbler. And um, it was not even easy to write because I have seen her handwriting. I have seen my father's handwriting. She taught him to write and ah, the words are um, disjointed letters, almost like a cross between writing and printing." ${ }^{62}$

Campbell herself describes the way that her sister Hannah taught her children to read and write, even when struggling to provide for her family as a single mother: "She [Hannah] brought up her first family of little children when their father died, teached them all to read and write only in the long winter nights, and hunt with them in the day, got about a dozen foxes and as many martens, take the little ones on the sled, haul them on over snow and ice to a large river, chop ice, about 3 feet thick ice, catch 2 or 3 hundred trout, large ones, and haul them and the children home, perhaps in the night" (4 December 1894).

The Campbell sisters, then, passed on the valuing of literacy. It was a gift that continued to be passed from generation to generation.

It is therefore not surprising that we have records of significant amounts of writing from two of Lydia Campbell's children. Her son, Thomas Blake, who was taught to read and write by his mother, kept a daily journal, recording the details of the weather and his daily work, travel, and social activities. ${ }^{63}$ While it does not contain the kinds of lengthy narratives found in Campbell's writing, Blake's journal suggests that he, like his mother, valued keeping a written record of his life. He also appears to have been a reader, as he records that, during a visit to Nova Scotia, he bought several books. ${ }^{64}$ Blake's style of journal-keeping was common among the Inuit Metis, though

6I Jean Crane is the daughter of Gilbert Blake, the guide who led Mina Hubbard on her famous expedition through the interior of Labrador; see Mina Hubbard, A Woman's Way Through Unknown Labrador (first published 1908; Montreal: McGill-Queen's University Press, 2004). Gilbert was the son of Thomas Blake and Sarah Jane Oliver.

62 Jean Crane, interviewed by Peter Gzowski, transcript by Karen Rukowski (I98I), p. 6, Them Days Archives.

63 Thomas L. Blake, The Diary of Thomas L. Blake (Happy Valley-Goose Bay, NL: Them Days, 2000).

64 Blake, Diary of Thomas L. Blake, 31. 
many of these journals have not survived. ${ }^{65}$ For instance, Maggie Campbell, ${ }^{66}$ Lydia's granddaughter, kept journals for her entire adult life. All but one of these were destroyed by being stored in a damp space after her death. The one remaining journal, much like Blake's, includes notes on daily life, records of the weather and of travels and visits, financial notations, and to-do lists. ${ }^{67}$

Lydia Campbell's daughter, Margaret Baikie, ${ }^{68}$ followed more closely in her mother's footsteps by writing a reflective and continuous autobiography, Labrador Memories, in the 1920s, when she was in her seventies. Her narratives are generally more lengthy and detailed than Campbell's; she also retells several of the oral histories that Campbell also recounted, often adding further details (while omitting others). While Baikie's memoirs remained unpublished in her lifetime, she was obviously proud of her writing, offering her manuscript to visitors to read. Harry Paddon, a visiting doctor, recalled in his 1938 memoirs that, on visiting Baikie, "I was privileged to read the reminiscences of an old widow," and he goes on to describe her stories in some detail. ${ }^{69}$ Blake's and Baikie's writings were kept by their families and eventually published by Them Days.

The autobiographical tradition started by Lydia Campbell also continued with Elizabeth Blake Goudie (1902-1982). Goudie was a descendant of Lydia Campbell's sister, Hannah. ${ }^{70}$ While she received only four years of formal schooling, Goudie recalls that reading was part of her daily life: "The Bible was read daily in the homes. That was the last thing that was done at night." ${ }^{\text {71 }}$ In the tradition of Lydia Campbell and Margaret Baikie, Goudie waited until late in life to

65 My mother, who grew up on the coast of Labrador, recalls that many of the "old people" kept daily journals.

66 Maggie (Margaret) Campbell was the daughter of John Campbell, Lydia Campbell's son. She never married and, like her grandmother, hunted, trapped, and gathered into her old age. She was a prolific diary-writer who also taught her many nieces to write.

67 This diary is held by "Aunt Maggie's" descendents. Many thanks to my greataunt, Rachel House, for allowing me to read it.

68 Margaret Baikie (nee Campbell, I849-1940) was the oldest daughter of Lydia and Daniel Campbell.

69 Harry Paddon, The Labrador Memoir of Dr. Harry Paddon, 19I2-1938, ed. Ronald Rompkey (Montreal \& Kingston: McGill-Queen's University Press, 2003), 67.

70 Elizabeth Goudie is a descendent of Hannah and her second husband, Merceille Michelin. She explains her family tree in detail in Woman of Labrador (Halifax: Nimbus, 1996), 23-25.

7I Goudie, Woman of Labrador, 27-28. 
write her life story, finishing it in 1971. ${ }^{72}$ Her pride in her work and in her culture also echoes Campbell's: "I would like to see this writing of our life and the life of the Labrador trappers published. These people all knew each other and were always happy to get together ... It was a good life, a very plain life. Just poor people - most of us were alike, but life didn't seem hard. We were honest with each other, and if you had two meals of meat and your neighbour had none you shared with him."73 Like Lydia Campbell, Goudie had a non-Labradorian take an interest in her writing. Her autobiography was edited by David Zimmerly, an anthropologist doing research in Labrador. Zimmerly wrote an introduction and sought publication for the book. It was published by Ottawa's Peter Martin Associates in 1973, under the title Woman of Labrador, and received national interest.

Benjamin Powell (b. 192I), ${ }^{74}$ Lydia Campbell's great-grandson, is also a writer and has published many works about his own life and Labrador history more generally; his best known work is Labrador by Choice. ${ }^{75}$ Millicent Blake Lodor (b. 1915), ${ }^{76}$ Campbell's greatgranddaughter, published Daughter of Labrador, her story of working as a nurse in Labrador. ${ }^{77}$ And Max Blake, a descendant of Lydia's sister, Hannah, has self-published several works; some are descriptions of Labrador history and culture and others are political tracts about Labrador independence. ${ }^{78}$ It is difficult to prove literary influence, and no doubt the writers that followed Lydia Campbell were led to write by myriad factors. But when we consider the wealth of writing that has emerged from this extended family since 1895, it seems clear that Lydia Campbell's Sketches of Labrador Life introduced to her descendants the possibility of book-writing and the belief that their lives were worth writing about. As Bill Rompkey, a long-time

72 David Zimmerly, "Introduction," in Woman of Labrador, vi.

73 Goudie, Woman of Labrador, 194.

74 Benjamin Powell is the grandson of John Campbell, Lydia and Dan Campbell's eldest son.

75 Benjamin Powell, Labrador by Choice ([Charlottetown, NL]: Benjamin Powell, 1979; repr. Jesperson Books, 1984).

76 Millicent Blake Lodor is a descendent of Thomas Blake, Lydia Campbell's eldest son.

77 Millicent Blake Lodor, Daughter of Labrador (St John's: Harry Cuff Publications, 1989).

78 Max Blake, Central Labrador Metis ([Rigolet, Labrador]: Max Blake, [1999]); Max Blake, Why Labrador Will Separate from Newfoundland: True Stories of Newfoundland's Exploitation of Labrador's Resources and Neglect of Labrador's People ([Rigolet, Labrador]: Max Blake, [1998]). 
Member of Parliament for Labrador, comments, "The descendents of Lydia Brooks Campbell still carry on the story of Labrador Life that she began." 79

Arguably, however, the strongest link in the chain of literary connections that flowed from Lydia Campbell was Doris Saunders (194I-2006). Saunders, Campbell's great-great-granddaughter, was 34 years old when she became the editor of a new quarterly magazine about Labrador history, entitled Them Days (est. 1975). For the next 30 years, Saunders was the driving force behind Them Days, collecting many hundreds of oral histories from people across Labrador, especially older people, and painstakingly transcribing them. ${ }^{80}$ In fact, only a fraction of these transcribed histories ever appeared in Them Days. The typescripts, which fill many filing cabinets in the Them Days archives in Happy Valley, Labrador, constitute an invaluable record of a community and their stories. Widely read within Labrador, Them Days has helped to sustain and strengthen a sense of identity and pride among Labradorians. In addition to oral histories, Them Days also published old photographs and autobiographical writings by Labradorians. Saunders explains that, shortly after she began publishing Them Days, she heard about Lydia Campbell's writings from Elizabeth Goudie. ${ }^{8 \mathrm{I}}$ Them Days went on to publish excerpts from Campbell's writings and finally created a chapbook of Sketches of Labrador Life in $1980 .{ }^{82}$ In doing so, Saunders made Campbell's writing accessible to Labradorians.

But more than being Lydia Campbell's editor and the force behind her republication, Doris Saunders also would go on to be strongly influenced by Campbell. In her foreword to a later edition of Campbell's work, Saunders wrote, "When Gran Campbell, as she is referred to by her descendants, wrote the memories of her family I wonder if she realized how important it would be to so many people years later." ${ }^{83}$ A look through Saunders' interview transcripts and her own writing reveals just how important Campbell's writings were to

79 Bill Rompkey, The Story of Labrador (Montreal: McGill-Queen's University Press, 2003), 176.

80 While there were many others who worked as researchers for the magazine, Saunders did a large part of the work herself.

8I Doris Saunders, "Foreword," in Sketches of Labrador Life by Lydia Campbell (St John's: Killick Press, 200o), ix.

82 Lydia Campbell, Sketches of Labrador Life, ed. Doris Saunders (Happy Valley, NL: Them Days, 1980).

83 Saunders, "Foreword," ix. 
her. In her interviews, she was clearly interested in stories about Lydia Campbell. For instance, in an interview with Flora Baikie, Saunders asks, "Would you tell us some stories that Grandmother used to tell you, Grandmother Campbell?" ${ }^{34}$ Over her years at Them Days, she collected many stories about Lydia Campbell. She eventually compiled these many stories into a single text; among Saunders' papers in the Them Days archives is this unpublished rewriting of Campbell's life story. It is a first-person narrative, written in Lydia Campbell's fictionalized voice. While some passages in the piece are taken directly from Campbell's autobiography, Saunders has added further stories, facts, and historical context, creating a text that could be said to represent the collective memory that exists in Labrador of Lydia Campbell's life. ${ }^{85}$ Stories of Campbell are also prominent in Saunders' unpublished essay, "Women in Labrador," in which she describes the role of women in Labrador, drawing parallels between Labrador women across generations. For instance, she connects her own happy marriage, in which she had "never been prevented from pursuing [her] dreams by [her] husband," with Campbell's relatively egalitarian marriage to Dan Campbell: "she taught him everything there was to know about trapping, fishing, and any other skills he should know ... her account of her life shows that they were happy together." ${ }^{\prime 86}$ It seems clear that Doris Saunders connected her own identity, as a strong woman, a Labradorian, and a writer, to Lydia Campbell.

Beyond the many literary Labradorians whom we can see as part of a writing tradition started by Lydia Campbell, many other Labradorians also see themselves as tied to Campbell and her writing. For instance, in 198I, Jean Crane, Lydia Campbell's great-granddaughter, when being interviewed by Peter Gzowski, commented, "I'm sort of another Lydia," going on to explain that she dressed up as Campbell for a local documentary, wearing "a cameo broach and mukluks" and carrying a "scribbler." 87 Crane further explained that her children and grandchildren know all about Lydia Campbell:

84 Doris Saunders with Irene Hope, in interview with Flora Baikie, North West River, 1977, transcript, p. 4. Tape Fi89, Them Days Archives.

85 Doris Saunders, "Old Lydia Campbell," unpublished manuscript, date unknown, Them Days Archives.

86 Saunders, "Women in Labrador," 3-5.

87 Crane, interview with Gzowksi, 4-6. 
Crane: I have 6 children and they're all married but one. He's 2 I. And I have I4 grandchildren.

Gzowski: Now, do they have a sense of Lydia Campbell and will they, will they carry on her strength and her traditions? Will they have any sense of life?

Crane: Yes, they do. And it's largely, you know, thanks to 'Them Days'... We in our family have always talked about our roots, ah Lydia, and other people behind us or back of us. But, ah, our children now have the full story of Lydia. ${ }^{88}$

In particular, Campbell's writings have been influential is strengthening an Inuit Metis identity in Labrador. We can see the beginnings of this distinctive identity in Campbell's writing. As Hulan points out, "When Campbell describes the decline of the Inuit, which she blames on alcohol and tobacco, she never includes herself among the afflicted population. ${ }^{89}$ However, notably, she also does not identify herself as among "the white people" (Io December I894) or the "English" (I8 December 1894). She notes that, to the Innu, her family were "white people as they called us" (I2 December I894), suggesting that that was not what they called themselves. Instead, she repeatedly refers to herself and her family as "half-breeds": "Such was life among the half-breeds in Esquimaux Bay" (24 December 1894). The beginnings of a distinctive "half-breed," or what has more recently been called "Metis," identity in Labrador is seen in Campbell's writing. This group identity, which is distinct from both "white" and Inuit identities, has long been recognized by both Labradorians and visitors from the outside, ${ }^{9 \circ}$ and it lives on in Labrador. For many Labradorians, Lydia

88 Crane, interview with Gzowksi, 4-5.

89 Hulan, Northern Experience, 82-83.

90 John McLean, for example, wrote in I849: "The Esquimaux half-breeds are both industrious and ingenious; they are at a loss for nothing. The men make their own boats, and the women prepare everything required for domestic convenience; almost every man is his own blacksmith and carpenter, and every woman a tailor and shoe-maker. They seem to possess all the virtues of the different races from which they are sprung - except courage; they are generally allowed to be more timid than the Natives. But if not courageous, they possess virtues that render courage less necessary; they avoid giving offence and are seldom, therefore, injured by others" (Notes of a Twenty-Five Years' Service, I62). In the early twentieth century, W.M. MacGregor, Governor of Newfoundland, made similar comments: "With such racial tendencies on the coast of Labrador as have been shewn above, the stamp and character of the 'settler,' of the new race that is springing up there, comes to be a matter of very special interest. Several of the missionaries incline to prefer the native, pure-blooded Innuit to the 'settler,' holding that the former is more open, more simple-minded, 
Campbell's stories have become founding stories that help define what it means to be Metis. For instance, when Chris Montague, ${ }^{9 \mathrm{I}}$ current president of the Labrador Metis Nation, was asked which stories he particularly remembered from his upbringing, he spoke of Lydia, her parents, and her sister Hannah. In his response, he blends together stories from his reading of Sketches of Labrador Life with stories from the Labrador oral tradition:

Oh yes, of course, say, the origins of the Brooks family and, of course, my ancestors Susan and Ambrose [Lydia Campbell's parents], the type of people they were. ["What type of people were they?"] I think they were great people who were the matriarch and patriarch of most of the people of Labrador. People who had lesser values than them died out in the area. They had strong faith, they had strong cultural values, they had a great respect for other people, other cultures living in the area, and they had a great sense of pride in who they were. They had a great appreciation of faith and of education and they were very resilient people. I think of the time that my great great, I guess, great grandmother Susan killed a polar bear when she was attacked by it. I hear the story down in Charlottetown that she choked it with a trout stick type chisel on a mitt. Our story is that she had an ulu tied on the end of a stick that she rammed up the throat of the polar bear. [Note that neither of these stories appear in Lydia's writings; they have been orally transmitted.] The story of the trout stick really belongs to my great-great grandmother, Hannah. Her daughter was attacked by a wolverine, one of the fiercest animals around, she killed it with a trout and that's written down in Lydia's diary actually. She said she admired Hannah for her braveness but I guess you look at, you read Lydia's diary you find she was very brave also. ${ }^{92}$

more genuine, more manageable, and of a milder disposition than the 'settler.' Others declare that the 'settler' is equally sober, more industrious, superior as a fisherman and hunter, more enterprising and hardier. But all agree in giving a much higher character to the 'settler' than I have ever known to be given to any other half-caste race in the British Empire. Indeed, in this case the half-breed appears to have inherited many of the best characteristics of both races." Reports of His Excellency Sir W.M. MacGregor, G.C.M.G., C.B., M.D. \& c., Governor of Newfoundland, of Official Visits to Labrador, Igos and I908, typescript, p. IO2-IO3, Them Days Archives.

9I Chris Montague is a descendent of Hannah, Lydia Campbell's sister.

92 Chris Montague, interview with Kristina Fagan (North West River, Labrador: unpublished, 2006). The story of a woman who kills a polar bear by choking it with a mitten on the end of a stick or ice chisel is part of Inuit oral traditions across the Arctic. It appears that, over the centuries, this oral tradition has 
Montague's proud comments about Lydia Campbell's family are clearly also intended to be a comment on his own identity and values and on those of the Inuit Metis in general. Campbell's written stories have blended with oral traditions to become part of the collective memory and identity of the Inuit Metis.

This essay places Lydia Campbell's Sketches of Labrador Life by a Labrador Woman within the context of Campbell's own community, the Inuit and Inuit Metis of Labrador. Rather than depicting Campbell as a fragmented or assimilated subject of colonialism, I argue that she had a cohesive and positive identity that built on both her Inuit and English parentage. Moreover, rather than understanding her literacy as a sign of her assimilation to colonial culture, I view literacy as a tool that she saw as her own and that she used for her own purposes. In so doing, she founded a tradition of writing which has extended down though her descendents and has strengthened the pride and identity of many generations of Labradorians. By focusing on the role of her book in her own indigenous context, the ways that she was she has been "significant 'round these here parts," we get a much richer, more complex, and more positive understanding of Campbell's book than can be achieved by placing it in a post-colonial context. Campbell writes, "You can say, well done old half breed woman in Hamilton's Inlet." As one of her many descendants, I hope that this essay is one way of saying just that. ${ }^{93}$

\section{SOMMAIRE}

Lydia Campbell (I818-1905), une femme écrivain du Labrador d'ascendance inuit et anglaise, publia par tranches en I894 et I895 son autobiographie Sketches of Labrador Life by a Labrador Woman. L'œuvre de Campbell remet en question plusieurs idées reçues en lien avec la littérature autochtone, notamment le schéma typique de l'écriture aborigène qui oppose le Blanc à l'Autochtone ou encore le colonialisme à la résistance. Au lieu de mettre l'accent sur cet antagonisme, cet article tente de replacer Campbell dans les coutumes indigènes et la tradition littéraire du Labrador en explorant

blended with the oral history of Susan's long walk from Rigolet to Mulligan, during which she encountered bears.

93 I would like to dedicate this essay to my niece, Lydia Fagan Dandeneau, who was born just as I finished writing it. Lydia, may you someday find strength and inspiration in the stories of your namesake. 
les contextes historiques et culturels dans lesquels l'auteure œuvra ainsi que l'influence qu'apporta son livre parmi les Métis inuits du Labrador. À propos de sa double identité d'Inuit et d'Anglaise, on fait valoir que Campbell se forgea une image qui ne manqua pas de positivité ni de cohésion. On souligne en outre que sa connaissance de l'alphabet, au lieu d'être un signe d'assimilation à la culture coloniale, s'avéra plutôt être un outil qu'elle perçut comme sien et qu'elle utilisa à ses propres fins pour instaurer une tradition d'écriture qu'elle transmit à la postérité. 
Appendix: Family Tree of Ambrose Brooks and Susan [Inuit Name Unknown], their children and grandchildren (with more detail provided for Lydia Campbell's line)

Ambrose Brooks (c. 1780 - I5 March 1852), England m. Susan ([?] - c. I829), Hamilton Inlet, Labrador

I. Elizabeth (c. 1808 - c. I85I) m. William Reid, Hamilton Inlet

Children: 3 children died with their parents in a shipwreck

2. Hannah (c. 1813 - c. 1895$)$

m. William Mesher, Hamilton Inlet

Children: Robert; Ambrose; Esther

m. Merceille Michelin, Trois Rivieres, Quebec

Children: Joseph; Peter; John; Helen; Emily; Alice; Elizabeth

3. Lydia (I November I818 - 29 April 1905)

m. William (Bill) Blake (c. 1793 - I845), Double Mer, Labrador Children:

I. Sarah (?)

2. Thomas (I843- I935)

m. Hester Ann Sheppard (I857 - I882)

m. Sarah Jane Oliver Blake ([?] - 1892)

m. Mary Goudie

$\mathrm{m}$. Caroline Osmond

3. Susan (I84I - [?])

m. David Irving, HBC Employee

4. name unknown

5. name unknown

m. Daniel Campbell (I822 - I2 August 19I2), South Ronaldsey, Orkney

Children:

I. Margaret (6 May I849 - I940)

m. Thomas Baikie (c. I838 - I913), Birsey, Orkney

2. John (I85I - 3 January I934)

m. Martha Davis, Cartwright, Labrador

3. Helen (1853-8 March I875) 
4. Donald (I857 - [?])

m. Elizabeth Ann Blake (1870 - [?]), Lolands, Esquimaux Bay, Labrador

5. James Brooks ([?] - I867)

6. Alexander ([?] - 8 January I88I)

7. Hugh Palliser (Inuit, adopted)

m. Druscilla Best ([?] - I9I8) 